\title{
Effect of Drying on Quality and Sensory Attributes of Lemongrass (Cymbopogon citratus) Tea
}

\author{
Phumudzo Mabai ${ }^{1}$, Adewale Omolola ${ }^{1} \&$ Afam I. O. Jideani ${ }^{1}$ \\ ${ }^{1}$ Department of Food Science and Technology, University of Venda, South Africa \\ Correspondence: Afam I. O. Jideani, Department of Food Science and Technology, University of Venda, P.M.B \\ X5050, Thohoyandou, 0950. South Africa. E-mail: Afam.Jideani@univen.ac.za
}

Received: September 29, 2017

Accepted: October 13, 2017 Online Published: February 13, 2018

doi:10.5539/jfr.v7n2p68

URL: https://doi.org/10.5539/jfr.v7n2p68

\begin{abstract}
The aim of this study was to investigate the effect of drying on quality and sensory attributes of lemon grass (Cymbopogon citratus) tea. Lemongrass (C. citratus) leaves were dried using four different drying methods: sun, solar, oven $\left(40,50\right.$, and $\left.60^{\circ} \mathrm{C}\right)$, and microwave $(50 \mathrm{~W})$. Teas made from the grass were analyzed for colour, $\mathrm{pH}$ and sensory attribute. Data obtained were statistically analyzed using SPSS Version 23 one way analysis of variance and means were compared using Duncan multiple comparison test $(\mathrm{p}<0.05)$. Results obtained indicate that after drying the moisture content were significantly reduced. Ash content results showed no significant difference amongst lemongrass samples dried under difference drying methods. However, there was a significant difference $(\mathrm{p}<0.05)$ in the $\mathrm{pH}$ of tea made from the lemongrass dried under different drying methods. Results indicate that drying temperature and time are the main factors affecting the colour of dried lemongrass leaves for tea. There was a significant difference $(p<0.05)$ in the colour profile of the dried leaves. Sensory evaluation results showed that the colour, aroma, taste, and overall acceptability scores of tea from lemongrass dried with oven at $40^{\circ} \mathrm{C}$ was highest. The study revealed that oven drying at $40^{\circ} \mathrm{C}$ for 15 hours was found to be most suitable for drying of lemongrass leaves for tea production in order to retain appreciable sensory attributes.
\end{abstract}

Keywords: lemongrass, drying methods, tea, organoleptic properties, chemical properties, sensory evaluation

\section{Introduction}

It is generally accepted that tea is one of the most popular beverages in the world. The demand for high-quality dried food products is permanently increasing all over the world. The main purpose of drying is to extend product shelf life, minimize packaging requirements and reduce shipping weights (Hamrouni-Sellami et al., 2012). Drying process increases the shelf life by slowing microbial growth and thus preventing certain biochemical reactions that might alter the organoleptic characteristics (Díaz-Maroto et al., 2003; Hamrouni-Sellami et al., 2012). Lemongrass (Cymbopogon citratus) is an herb that belongs to the genus Cymbopogon of aromatic grasses and contains essential oil with fine lemon flavour (Nur Ain et al., 2011). It is a tallperennial grass widely cultivated in Brazil for medicinal purposes, especially as tea and its essential oil (Martinazzo et al., 2009); grows up to $90 \mathrm{~cm}$ in height and $5 \mathrm{~mm}$ wide (Nur Ain et al., 2013); is highly sought after in the nutritional, pharmaceutical and flavouring industries (Lonkar et al., 2013). Cultivated on a large scale, especially in tropics and subtropics (Akhila, 2010), lemongrass is commonly used in folk medicine for treatment of nervous and gastrointestinal disturbances, and as an antispasmodic, analgesic, anti-inflammatory, anti-pyretic, a diuretic and a sedative (Brian \& Ikhlas, 2002; Santin et al., 2009; Lodhi et al., 2014). It contains active ingredients like myrcene, an anti-bacterial and the pain relievers, citronella, and geraniol (Blanco et al., 2009). India is the largest producer of lemongrass of which about $80 \%$ is exported. Leite et al. (2000) also reported that lemongrass tea can be used to treat fevers, colds, coughs and stomach upset. With its wide use as an ingredient for cooking, Berry (2004), describes lemongrass as the rising star in the herbal world, having both floral and fragrant characteristics that add an instant exotic appeal to food and beverages.

Teas from various sources are available in popular flavours (spicy, smoky, cinnammon-like, sweet ether-like, weak sulfurous) and are consumed for amongst other benefits, their antioxidant properties (Hara, 1994; Hengel and Shibamoto 2013). Lemongrass tea has a flavour very true to the flavour of the herb itself, a characteristic lemon flavour due to its composition, rich in volatile oils that present chemical components of great importance to the industry (Barata et al 1998). This study investigated the effect of drying on quality and sensory attributes 
of freshly harvested lemongrass (Cymbopogon citratus) tea.

\section{Materials and Methods}

\subsection{Sample Collection and Preparation}

Fresh leaves of lemongrass were collected with permission from a farmer in Matangari Village in Limpopo province, South Africa. The samples were selected on the basis of fresh green leaves. The leaves were washed with water and cut into small pieces with a clean scissors/stainless steel knife (Lonkar et al., 2013). All procedures including tests were performed in triplicate.

\subsection{Drying Experiments}

Fifty (50) g of fresh chopped green lemongrass were dried using sun, solar dryer (Janjai et al., 2002),microwave (model P70B17L-T8)at $50 \mathrm{~W}$, and oven (Prolab Instrument - model OTE 80) at $40^{\circ} \mathrm{C}, 50^{\circ} \mathrm{C}, 60^{\circ} \mathrm{C}$ (Lonkar et al., 2013; Nur Ain et al., 2013). During the drying process, the weight of the sample were monitored at regular intervals (hourly) using weighing balance (ADAM AAA 300L/PW 254) and the process was stopped at a point where the weight of the sample remained constant (Lonkar et al. 2013). The dried lemongrass was stored in an airtight bag plastic bag until further analysis (Lonkar et al., 2013 \& Nur Ain et al., 2013).

\subsection{Quality Analysis}

\subsection{1 $\mathrm{pH}$ of Dried Lemongrass Leaves}

A pH meter (Crison instrument, 042030, S.A) was used to assess the $\mathrm{pH}$ of each sample. Fresh standardization solutions of $\mathrm{pH} 4.01,7.00$, and 9.21 were used to standardize the instrument before using and after every five or six reading (Vargas et al., 2008).

\subsubsection{Colour of Lemongrass Tea}

A colorimeter (Hunter Lab $\mathrm{s} / \mathrm{n}$ : cx2540) was used to measure the $L^{*}$ (Lightness), $a^{*}$ (Redness), and $b^{*}$ (Yellowness) colour parameters of each tea sample. The colorimeter was calibrated with a standard white $\left(\mathrm{L}^{*}=\right.$ $93.71, \mathrm{a}^{*}=-0.84$ and $\mathrm{b}^{*}=1.83$ ) and black plate prior to each colour measurement.

\subsubsection{Moisture Content of Dried Lemongrass Leaves}

Dried lemongrass cuts $(3 \mathrm{~g})$ were dried in pre-weighed crucibles in an oven at $105^{\circ} \mathrm{C}$ for 3 hours, and cooled in desiccator for $30 \mathrm{~min}$. Moisture content was calculated from difference in weight according to A0AC, 2007 method number 945.32. The following formula was used to calculate the moisture content (MC) of dried lemongrass:

$$
\mathrm{MC} \%=\mathrm{W}_{2}-\mathrm{W}_{3} / \mathrm{W}_{2}-\mathrm{W}_{1} * 100
$$

where:

$\mathrm{W}_{1}=$ Initial weight of empty crucible

$\mathrm{W}_{2}=$ Weight of crucible + samples prior drying

$\mathrm{W}_{3}$ = Final weight of crucible + sample after drying

\subsubsection{Ash Content of Dried Lemongrass Leaves}

Dried samples ( $3 \mathrm{~g}$ ) in pre-weighed crucibles were transferred and kept in a muffle furnace at $550^{\circ} \mathrm{C}$ overnight and left until a light grey ash resulted, and cooled in a desiccator for $30 \mathrm{~min}$ before weighing (Aftab et al., 2011). The following formula was used to calculate ash content (AC) of lemongrass samples.

$$
\mathrm{AC} \%=\mathrm{W}_{3}-\mathrm{W}_{1} / \mathrm{W}_{2}-\mathrm{W}_{1} * 100
$$

where:

$\mathrm{W}_{1}=$ Weight of empty crucible

$\mathrm{W}_{2}=$ Weight of crucible + samples prior drying

$\mathrm{W}_{3}=$ Final weight of crucible + ash

\subsection{Preparation of Tea from Dried Lemongrass Leaves}

The unsweetened lemongrass teas were prepared using each of the dried samples as follows: sample (18 $\mathrm{g}$ ) was weighed and put into a flask $(1.8 \mathrm{~L})$ to which boiling water $\left(99.7^{\circ} \mathrm{C}\right)$ was added. The teas were left to brew for 5 min and then passed through a $106 \mu \mathrm{m}$ sieve. The tea was not sweetened. 


\subsection{Sensory Evaluation of Tea}

Sensory evaluations of the teas brewed as described above were conducted in the Department of Food Science and Technology using 50 untrained panellists. The lemongrass tea were evaluated with respect to colour, aroma, taste, and overall acceptability using the 5-point hedonic scale where 1 represents dislike extremely and 5 like extremely respectively. Tea samples were coded and served randomly to panellists to avoid bias (Hashin et al., 2009). About $30 \mathrm{ml}$ of each tea samples was served in a $120 \mathrm{ml}$ paper cup. The tea samples were approximately $67.2^{\circ} \mathrm{C}$ at the time of tasting. The panellist were served and instructed to rinse their mouth with warm water $\left(45.7^{\circ} \mathrm{C}\right)$ in between evaluating each tea sample to minimize the lingering tastes (Meilgaard et al., 1999).

\subsection{Statistical Analysis}

The statistical software package SPSS Version 23 program was used to analyse all experimental data collected. All comparisons were subjected to a one-way analysis of variance (ANOVA), and significant differences between treatments means were determined using Duncan's multiple range test (Duncan, 1955) at $\mathrm{p}<0.05$.

\section{Results and Discussion}

\subsection{Moisture Content of Fresh Lemongrass Leaves}

The initial moisture content of the freshly harvested lemongrass samples was found to be $73 \%$. It could be observed from Table 1 that the final moisture content of lemongrass samples varied with respect to the different drying methods.

Table 1. Effect of drying methods on moisture content of dried lemongrass

\begin{tabular}{llll}
\hline Drying methods & Temperature $\left({ }^{\circ} \mathbf{C}\right)$ & Time (h) & Final moisture content (\%) \\
\hline Sun & 34.7 & 10 & $3.33 \pm 2.89$ \\
Solar & 50.6 & 8 & $5.00 \pm 0.00$ \\
Oven & 40 & 15 & $5.00 \pm 0.00$ \\
& 50 & 8 & $5.00 \pm 0.00$ \\
\multirow{2}{*}{ Microwave } & 60 & 6 & $2.10 \pm 0.00$ \\
& Power $(\mathbf{W})$ & & \\
& 50 & 0.9 & $3.33 \pm 2.89$ \\
\hline
\end{tabular}

The final moisture contents of lemongrass samples ranged from 3.33 to $5.00 \%$. The moisture content was in the range of $0 \%-5 \%$ for different drying conditions. Products dried using sun and microwave at $50 \mathrm{~W}$ had similar (3.3\%) amount of moisture content, however the highest (5\%) amount of moisture were in solar, oven at $40^{\circ} \mathrm{C}$, and $50^{\circ} \mathrm{C}$ while the lowest $(0 \%)$ was oven at $60^{\circ} \mathrm{C}$ (Table 1 ). The shelf stability of a food product depends on the moisture content i.e. the higher the moisture content, the lower the shelf stability and vice versa (Fennema, 1996). The moisture content of dried lemongrass tea leaf samples were within the recommended moisture content range (3-12\% (w/w) (Barbosa et al., 2008). This is an indication that all the dried samples are likely to stay longer before use or processing due to their low moisture content since the low moisture content of the leaves coupled with drying could hinder growth of microorganisms, hence storage life would be longer (Awogbemi \& Ogunleye 2009).

\subsection{Ash Content of Dried Lemongrass Leaves}

The ash contents of lemongrass samples dried under the different drying conditions is as shown in Figure 1. The ash content of lemon grass samples varies with respect to the drying conditions. The ash contents of lemongrass samples ranged from 6.67 to 7.78 , with oven dried at $\left(60^{\circ} \mathrm{C}\right)$ samples having the highest ash content $(7.78 \%)$ while sun, solar, oven $\left(40^{\circ} \mathrm{C}, 50^{\circ} \mathrm{C}\right)$ and microwave $(50 \mathrm{~W})$ had the same $(6.67 \%)$ ash content. Ash content is as a measure of the total amount of minerals present within a food. According to Kirk \& Sawyer (1997), the range of the ash content of dried samples is $5.2 \%$ to $7.2 \%$ for teas. Product dried by sun, solar, oven at $40^{\circ} \mathrm{C}, 50^{\circ} \mathrm{C}$, and microwave were within the recommended range of $5.2 \%$ to $7.2 \%$. This is an indication that lemongrass leaves has a considerable amount of minerals. However, oven at $60^{\circ} \mathrm{C}$ exceeded the recommended range of $5.2 \%$ to $7.2 \%$ since it has the highest $(7.78 \%)$ amount of ash, this could be attributed to the reduction in moisture content during drying that resulted in corresponding increases in dry mater content due to concentration of soluble solids (Tetteh, 2009). There was no significant difference amongst the ash content of lemongrass samples dried under difference drying methods (Table 2). 


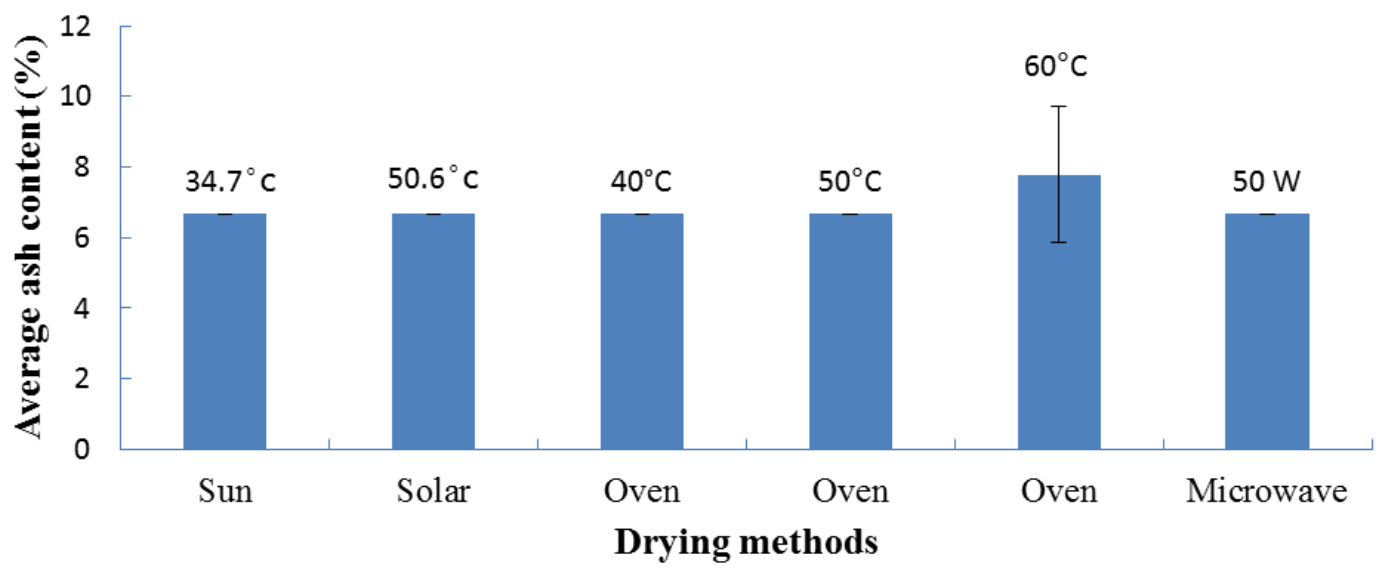

Figure 1. Average ash content of dried lemongrass under different drying methods

\section{3 pH Measurement of Lemongrass Leaves}

The lemongrass tea samples from different drying conditions gave $\mathrm{pH}$ readings as shown in Figure 2.It shows variation of ash contents of lemongrass samples with respect to the drying conditions. The $\mathrm{pH}$ contents of lemongrass samples ranged from 5.8 to 6.3 .Variation in $\mathrm{pH}$ might be attributed due to delay in drying, wherein the leaves started to ferment even though they were stored in the cold room before analysis. The variation in $\mathrm{pH}$ values could further be explained by factors such as exposure times to drying air, drying air temperature, relative humidity in the drying site, nature of drying air flow as previously indicated by Franke et al., (2008). Almost similar $\mathrm{pH}$ readings were obtained from the analysis of lemongrass in Ghana (De-heer, 2011). There was a significant difference amongst the $\mathrm{pH}$ of the samples dried under different drying methods (Table 3). De-heer (2011) conducted a study in Ghana on formulation and sensory evaluation of herb tea from Moringa oleifra, Hibscus scibdariffa and Cymbopogon citratrus and obtained a $\mathrm{pH}$ of 4.53. The $\mathrm{pH}$ found in this study was higher than that reported by De-heer (2011). This could possibly be due to variation in climatic condition and the soil types.

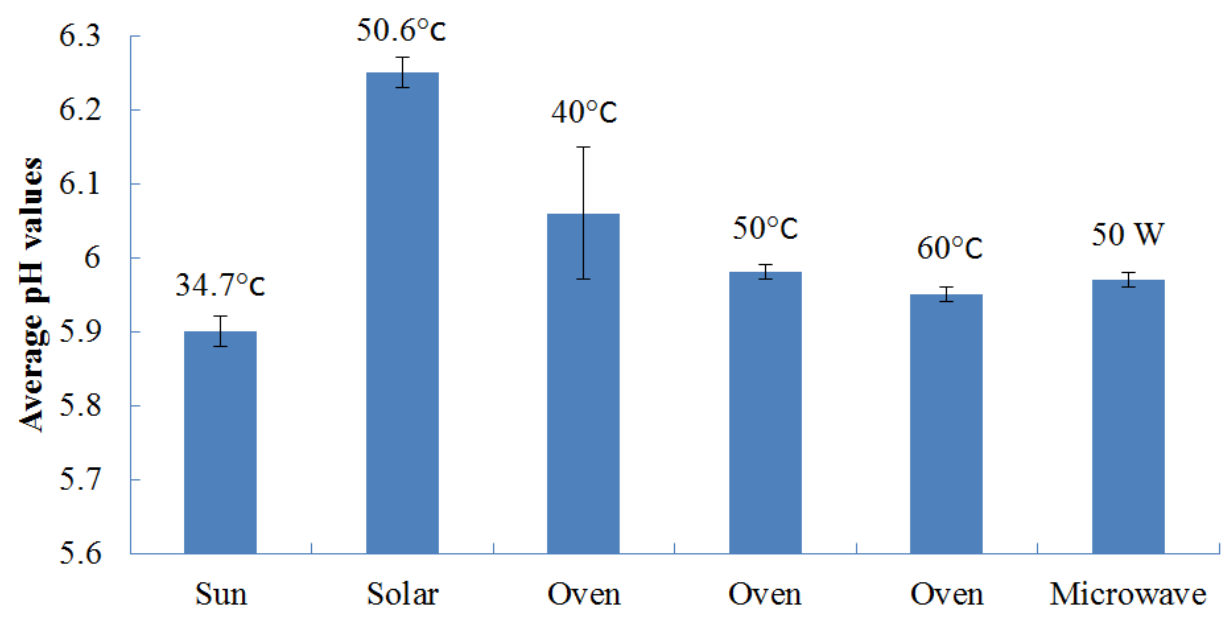

Drying methods

Figure 2. Average $\mathrm{pH}$ of dried lemongrass dried under different drying methods

\subsection{Instrumental Colour Analysis of Lemongrass Tea}

Colour is an important attribute of dried product from the consumer's acceptability view (Inchuen et al., 2010). It is also considered as an important quality indicator for acceptance of the final product in the market (Soysal, 2004).The results shows that drying temperature and time are the main factors affecting the colour of dried lemongrass leaves for tea. Similar observation was made by Somkiat et al., 2004 . Oven at $40^{\circ} \mathrm{C}, 50^{\circ} \mathrm{C}$, and $60^{\circ} \mathrm{C}$ (Table 2), shows the reduction in brightness value $\mathrm{L}^{*}$ of the dried lemongrass leaves as the drying temperature increases. These results agreed with the observation of Hoque et al., 2013. They reported that lightness L* 
decrease with an increase in drying temperature. These results again agreed with the observation of Sanmeema (2012). He reported that the colour parameters for $\mathrm{L}^{*}$ values were high at $40^{\circ} \mathrm{C}$ when compared with $50^{\circ} \mathrm{C}$ and $60^{\circ} \mathrm{C}$, this indicate that the dried products were darkened when the temperature increases. The highest $\mathrm{L}^{*}$ value was obtained in products dried by sun and oven at $40^{\circ} \mathrm{C}$, indicating the drying methods which are useful in maintaining the colour of the dried products. There was a significance difference $(p<0.05)$ between the $L^{*}$ values of lemongrass leaves dried under the difference drying methods. Negative a* values obtained for samples dried under sun, solar, oven at $40^{\circ} \mathrm{C}, 50^{\circ} \mathrm{C}$, and $60^{\circ} \mathrm{C}$, indicated that all lemongrass leaves dried under the different drying conditions were green. The lowest $\mathrm{a}^{*}$ values were obtained from solar drying with decreased greenness followed by oven at $40^{\circ} \mathrm{C}$, oven at $60^{\circ} \mathrm{C}$, oven at $50^{\circ} \mathrm{C}$ and sun respectively. However, microwave at $50 \mathrm{~W}$ was having a positive $\mathrm{a}^{*}$ value, indicating that the green colour was negatively affected and destroyed during drying. This was expected since the previous studies reported (Drouzas et al., 1999) that undesirable browning and reduced green colour of the microwave-dried product occurred in samples because of the high temperature generated by the microwaves. The $\mathrm{b}^{*}$ values indicating the yellowness of the samples varied from 12.98 to 18.74 . There was a significant difference $(\mathrm{p}<0.05)$ of yellowness from all drying methods.

\subsection{Sensory Evaluation of Lemongrass Tea Samples}

\subsubsection{Colour Acceptability}

Colour of a food surface is the first quality parameter evaluated by consumers and is critical in product acceptance, even before it is tasted (Youssef and Mokhtar 2014). Consumers expect food to look appetizing and the colour of food is usually associated with expected the flavour of food (Downham \& Collins 2000). Consumer responses on colour acceptability showed that, tea from microwave at $50 \mathrm{~W}$, oven $60^{\circ} \mathrm{C}$, and sun were least acceptable while the colour of oven $50^{\circ} \mathrm{C}$, solar, and oven $40^{\circ} \mathrm{C}$ were the most acceptable. Similar observation was made by Cuervo-Andrade (2011). Colour acceptability of the tea samples increased in order as follow: microwave at $50 \mathrm{~W}<$ oven at $60^{\circ} \mathrm{C}<$ sun $<$ oven at $50^{\circ} \mathrm{C}<$ solar $<$ oven at $40^{\circ} \mathrm{C}$ (Table 3). This indicates that samples from microwave at $50 \mathrm{~W}$, oven at $60^{\circ} \mathrm{C}$ and sun were negatively affected during drying. This agreed with the observation of Rahimmalek \& Goli (2013). They reported that oven drying at higher temperature resulted in a considerable decrease in the colour quality of celak leaves. Shaw et al. (2007) reported a significant colour change in coriander foliage under microwave drying process. Ozkan et al. (2007) also reported that the colour of spinach was adversely affected under microwave drying process at very high microwave powers. Rahman et al. (2013) reported that direct exposure to sunlight reduces the quality of lemongrass such as colour, flavour leading to the production of low and variable quality of products. There was a significant difference amongst the colour acceptability of the samples dried under different drying methods (Table 3 ). The colour acceptability was in a range of 2.58 to 3.56. A possible explanation for this low colour acceptability range could possibly be that consumers in the study area expect the colour of the tea to be black. Lemongrass tea is not known or consumed in the study area, and assessors used for evaluation of the tea acceptability are not familiar with the lemongrass tea unlike other commercial tea found in shopping malls in the study area. These are possibly the reason for low colour acceptability range observed in the study.

\subsubsection{Aroma Acceptability}

Lemongrass tea is expected to have a strong aroma (Baratta et al., 1998; Kasali et al., 2001; Nur Ain et al., 2011). This is due to its high concentration of aromatic oils. Results show variation in aroma acceptability of tea samples obtained using different drying condition in the range of 2.66 to 3.52. A possible explanation for the variation in aroma (2.66 to 3.52) might be that aroma producing compounds are generally volatiles or they get combined with other biomolecules when grinding samples for preparation of powder (Lonkar et al., 2013). There was a significant difference amongst the aroma acceptability of the samples dried under different drying conditions (Table 3). Consumer responses on aroma acceptability showed that, tea from microwave at $50 \mathrm{~W}$ (2.66), oven at $60^{\circ} \mathrm{C}(2.74)$, and sun (2.98) were least acceptable while the aroma of oven at $50^{\circ} \mathrm{C}(3.20)$, solar (3.24), and oven at $40^{\circ} \mathrm{C}(3.52)$ were most acceptable.

\subsubsection{Taste Acceptability}

Lemongrass tea has a flavour very true to the flavour of the herb itself. As the name suggests, the tea tastes lemon (Leite et al., 2000). Taste is one of the sensory properties which form the component of flavour of a product (Meilgaard et al., 1999). The result shows variation in taste acceptability of lemongrass tea samples obtained from different drying condition. There was a significant difference amongst the taste acceptability of the samples dried under different drying conditions (Table 3).Consumer responses on taste acceptability showed that, tea from oven at $40^{\circ} \mathrm{C}$, solar, and sun were the most acceptable while those dried by oven at $60^{\circ} \mathrm{C}$, microwave $50 \mathrm{~W}$, and oven at $50^{\circ} \mathrm{C}$ were least acceptable as shown in Table 3. Low taste acceptability scores 
which were in a range of 2.62 to 3.40 could be due to the observed elements in the tea.

\subsubsection{Overall Acceptability}

Results show that product dried using oven at $40^{\circ} \mathrm{C}$ had the highest mean score in overall acceptability (3.50) as shown in Table 3. This was expected as it was the most preferred product in colour (3.56), aroma (3.52), and in taste (3.40). The overall acceptability of the tea is based on the organoleptic properties such as colour of tea, aroma of tea and taste of the tea (Lonkar et al., 2013). Low scores on colour, aroma and taste acceptability due to the fact that consumers were not familiar with lemongrass tea. Consumers expect the colour of the tea to be black. They also expect the taste of the tea to be sweetened. Exposure of aroma forming compounds to the natural environment due to the use of various treatments of cutting and powder making (Lonkar et al., 2013) could be possibly have caused a lesser overall acceptance by panellists which was in a range of 2.56 to 3.50 despite the fact that the highest score was 3.50.There was no significant difference amongst the overall acceptability of the samples with high scores which are dried by sun, solar, oven at $40^{\circ} \mathrm{C}$, and oven at $50^{\circ} \mathrm{C}$ (Table 3). This indicate that these are the product which were most accepted by the panellist with respect to their colour, aroma, and taste. However, samples dried by oven at $60^{\circ} \mathrm{C}$ and microwave at $50 \mathrm{~W}$ were significantly different to samples dried by sun, solar, oven at $40^{\circ} \mathrm{C}$, and at $50^{\circ} \mathrm{C}$. This also indicate that products dried by oven at $60^{\circ} \mathrm{C}$ and microwave at $50 \mathrm{~W}$ were least accepted by the panellist with respect to their colour, aroma, and taste. These agreed with the observation of Rahimmalek \& Goli, 2013. They reported that oven drying at higher temperature resulted in a considerable decrease in the colour quality of the leaves. Shaw et al. (2007), reported about the colour changes occurring during drying of most of the leaves using microwave drying process. There is increasing need for methods and tools for determining the characteristics of tea varieties (Buyukgoz et al., 2016).

Table 2. Physicochemical analysis for lemongrass dried under different conditions

\begin{tabular}{lllllll}
\hline \multicolumn{5}{c}{${\text { Oven }\left({ }^{\circ} \mathbf{C}\right)}$} \\
\hline Properties & Sun & Solar & $\mathbf{4 0}$ & $\mathbf{5 0}$ & $\mathbf{6 0}$ & Microwave at 50 W \\
\hline $\mathrm{L}^{*}$ & $50.29 \pm 1.15^{\mathrm{a}}$ & $47.13 \pm 0.48^{\mathrm{b}}$ & $50.22 \pm 1.96^{\mathrm{a}}$ & $43.74 \pm 1.13^{\mathrm{c}}$ & $39.62 \pm 1.21^{\mathrm{d}}$ & $40.09 \pm 1.16^{\mathrm{d}}$ \\
$\mathrm{a}^{*}$ & $-0.86 \pm 0.49^{\mathrm{b}}$ & $-3.94 \pm 0.55^{\mathrm{d}}$ & $-2.15 \pm 0.19^{\mathrm{c}}$ & $-1.03 \pm 0.13^{\mathrm{b}}$ & $-2.11 \pm 0.58^{\mathrm{c}}$ & $1.44 \pm 0.14^{\mathrm{a}}$ \\
$\mathrm{b}^{*}$ & $12.98 \pm 1.05^{\mathrm{d}}$ & $13.21 \pm 0.76^{\mathrm{d}}$ & $15.23 \pm 0.67^{\mathrm{c}}$ & $13.55 \pm 0.70^{\mathrm{d}}$ & $18.74 \pm 0.90^{\mathrm{a}}$ & $16.81 \pm 0.33^{\mathrm{b}}$ \\
Ash & $6.67 \pm 0.00^{\mathrm{a}}$ & $6.67 \pm 0.01^{\mathrm{a}}$ & $6.67 \pm 0.02^{\mathrm{a}}$ & $6.67 \pm 0.03^{\mathrm{a}}$ & $7.78 \pm 1.92^{\mathrm{a}}$ & $6.67 \pm 0.03^{\mathrm{a}}$ \\
$\mathrm{pH}$ & $5.89 \pm 0.02^{\mathrm{d}}$ & $6.25 \pm 0.02^{\mathrm{a}}$ & $6.06 \pm 0.09^{\mathrm{b}}$ & $5.98 \pm 0.01^{\mathrm{c}}$ & $5.96 \pm 0.03^{\text {cd }}$ & $5.97 \pm 0.01^{\text {cd }}$ \\
\hline
\end{tabular}

Mean scores in the same row with different superscripts are significantly different $(p<0.05)$. $L^{*}=$ Lightness, $a^{*}$ $=$ Redness, $b^{*}=$ Yellowness.

Table 3. Sensory analysis for lemongrass tea dried under different drying conditions

\begin{tabular}{|c|c|c|c|c|c|c|}
\hline & & & Oven $\left({ }^{\circ} \mathbf{C}\right)$ & & & \\
\hline $\begin{array}{l}\text { Sensory } \\
\text { properties }\end{array}$ & Sun & Solar & 40 & 50 & 60 & $\begin{array}{l}\text { Microwave } \\
\text { at } 50 \mathrm{~W}\end{array}$ \\
\hline Colour & $2.98 \pm 1.27^{\mathrm{bc}}$ & $3.46 \pm 1.27^{\mathrm{ab}}$ & $3.56 \pm 1.23^{\mathrm{a}}$ & $3.24 \pm 1.25^{\mathrm{ab}}$ & $2.94 \pm 1.32^{\mathrm{bc}}$ & $2.58 \pm 1.21^{\mathrm{c}}$ \\
\hline Aroma & $2.98 \pm 1.15^{\mathrm{bc}}$ & $3.24 \pm 1.22^{\mathrm{ab}}$ & $3.52 \pm 1.13^{\mathrm{a}}$ & $3.20 \pm 1.14^{\mathrm{ab}}$ & $2.74 \pm 1.34^{\mathrm{bc}}$ & $2.66 \pm 1.32^{\mathrm{c}}$ \\
\hline Taste & $3.02 \pm 1.15^{\mathrm{abc}}$ & $3.30 \pm 1.27^{\mathrm{ab}}$ & $3.40 \pm 1.12^{\mathrm{a}}$ & $2.84 \pm 1.29^{\mathrm{bc}}$ & $2.62 \pm 1.24^{\mathrm{c}}$ & $2.74 \pm 1.26^{\mathrm{c}}$ \\
\hline Overall acceptability & $3.34 \pm 0.98^{\mathrm{a}}$ & $3.40 \pm 1.23^{\mathrm{a}}$ & $3.50 \pm 0.91^{\mathrm{a}}$ & $3.16 \pm 1.17^{\mathrm{ab}}$ & $2.78 \pm 1.22^{\mathrm{bc}}$ & $2.56 \pm 1.31^{\mathrm{c}}$ \\
\hline
\end{tabular}

Mean scores in the same row with different superscripts are significantly different $(\mathrm{p}<0.05)$.

\section{Conclusion}

The study investigated the effect of drying on quality and sensory attributes of lemon grass (Cymbopogon citratus) tea. Results showed that the sensory properties, moisture content, ash content, $\mathrm{pH}$ and colour of lemongrass samples differ with respect to the drying methods used. Lemongrass tea from samples dried by oven at $40^{\circ} \mathrm{C}$ was the most preferred in colour, aroma, taste and overall acceptability. Oven drying at $40^{\circ} \mathrm{C}$ was found to be most suitable for drying of lemongrass leaves for tea production in order to retain appreciable sensory attributes.

\section{Reference}

Aftab, K., Ali, M.D., Aijaz, P., Beena, N., Gulzar, H.J., Sheikh, K., Sofia, Q., \& Tahir, Abbas, S.(2011). Determination of different trace and essential element in lemongrass samples by $\mathrm{x}$-ray fluorescence spectroscopy technique. International Food Research Journal, 18, 265-270. 
AOAC, (2007). Official methods of analysis of the association of official Analytical chemistry. 15th edition, pp 951-952.

Awogbeni, O., \& Ogunleye, I.O. (2009). Some selected vegetables. International Journal of Engineering Technology, 1, 1793-8236.

Banerjee, B. (1992). Botanical classification of tea. In: Willson K.C and Clifford M.N ed. Tea cultivation to consumption. London. Chapman and Hall. pp. 22-51. https://doi.org/10.1007/978-94-011-2326-6_2

Barbosa, L.C.A., Perema, U.A., Martinazzo, A.P., Maltha, C.R.A., Texera, R.R., \&Melo, E.D. (2008). Evaluation of the composition of Brazilian commercial Cymbopogon citratus (DC) Staph samples. African Journal of Biotechnology, 13, 1864-1874.

Baratta, M.T., Dorman, H.J.D., Deans, S.G., Figueiredo, A.C., Barroso, J.G., \& Ruberto, G. (1998). Antimicrobial and antioxidant properties of some commercial essential oils. Journal of Flavour Fragrance, 13, 235-244. https://doi.org/10.1002/(SICI)1099-1026(1998070)13:4<235::AID-FFJ733>3.3.CO;2-K

Berry, M.J. (2004). Antimicrobial activity of essential oil of local Serai Cymbopogon citratus. Journal of Bioscience, 3, 87-90.

Blanco, M.M., Costa, C.A., Costa, M., Freire, A.O., \& Santos, J.G. (2009). Neurobehavioral effect of essential oil of Cymbopogon citratus in mice. Phytomedicine, 16, 265-270. https://doi.org/10.1016/j.phymed.2007.04.007

Buyukgoz, G. G., Soforoglu, M., Akgu, N.B., \& Boyaci, I.H. (2016). Spectroscopic fingerprint of tea varieties by surface enhanced Raman spectroscopy. Journal of Food Science and Technology, 53, 1709-1716.https://doi.org/10.1007/s13197-015-2088-5

Brian, T.S., \&Ikhlas, A.K. (2002).Comparison of extraction methods for marker compounds in the essential oil of lemon grass by GC. Journal of Agriculture and Food Chemistry, 50, 1345-1349. https://doi.org/10.1021/jf011078h

Cuervo-Andrade, A. (2011). Quality oriented drying of lemongrass balm (Melissa officinalis L.). University of Kassel. Ireland. pp. 49-53.

Díaz-Maroto, M.C., Pérez-Coello, M.S., González Vinas, M.A., \&Cabezud, M.D. (2003). Influence of drying on the flavor quality of spearmint (Mentha spicata L.). Journal of Agriculture and Food Chemistry, 51, 1265-1269.https://doi.org/10.1021/jf0208051

Duncan, D. (1955). Multiply range and multiple F test. Biometrics, 11, 1-42. https://doi.org/10.2307/3001478

Downham, A., \& Collins, P. (2000). Colouring our foods in the last millennium. International Journal of Food Science and Technology, 35, 5-22. https://doi.org/10.1046/j.1365-2621.2000.00373.x

Drouzas, D.C.P., Annamalai, S.J.K., \&Naik, R. (1999). Effect of drying on the volatile oil yield of Patchouli. Indian Journal of Science and Technology, 6, 5559-5562.

Fennema, R.O. (1996). Water and Ice. In: Fennema, RO, Karel M, Sanderson GW, Tannenbaum SR, Walstra P, Witaker JR. (eds.) Food Chemistry, Marcel Dekker Inc. New York. 52.

Hamrouni-Sellami, I., Bettaieb, R.I., Sriti, J., Zohra, R.F., Limam, F., \& Marzouk, B. (2012). Drying sage (Salvia officinalis L.) plants and its effects on content, chemical composition, and radical scavenging activity of the essential oil. Food Bioprocess Technology, 5, 2978-2989.

https://doi.org/10.1007/s11947-011-0661-0

Hara, Y. (1994). Function of tea polyphenols. In Ho CT, Osawa T, Huang MT, Rosen RT (Eds.), Food phytochemicals for cancer prevention II. Washington, DC: American Chemical Society Press. pp. 34-50. https://doi.org/10.1021/bk-1994-0547.ch003

Hashin, I.B., Khalil, A.H., \& Afifi, H.S. (2009). Quality characteristics and consumer acceptance of yoghurt fortified with dietary fiber. Journal of Dairy Science, 92, 5403-5404. https://doi.org/10.3168/jds.2009-2234

Hengel, M., \& Shibamoto, T. (2013). Carcinogenic 4(5)-methylimidazole found in beverages, sauces, and caramel colors: chemical properties, analysis, and biological activities, Journal of Agricultural and Food Chemistry, 61, 780-789.https://doi.org/10.1021/jf304855u

Hoque, L.F., Kim, D.M., \& Lee, C.Y. (2013). Effects of heat processing and storage on flavonols and sensory qualities of green tea beverage. Journal of Agricultural and Food Chemistry, 48, 4227-4232. 
Inchuen, P., Narkrugsa, W., \& Pornchaloempong, P. (2010). Effect of drying methods on chemical composition, colour and antioxidant properties of Thai red curry powder. Kasetsart Journal, (Natural Science), 44, 142-151.

Janjai, S., Chantaraksa, W., Hirunlabh, J., Esper, A., Lauer, M., \& Muehlbauer, W. (2002). Investigation of the performance of a solar dryer for lemon-grass. University of Technology Thonburi, 3 Institute of Agricultural Engineering in the Tropics and Subtropics, Hohenheim University.

Kasali, A.A., Oyedeji, A.O., \& Ashilokun, A.O. (2001). Volatile leaf oil constituents of Cymbopogon citratus (DC) Stapf. Flavonoids Fragrance Journal, 16, 377-378. https://doi.org/10.1002/ffj.1019

Kirk, R.S., \& Sawyer, R. (1997). Pearson's Composition and Analysis of Foods (9th Ed) Longman Singapore Publishers; Singapore. 356-362.

Leite, J.R., Seabra, M.L., \& Maluf, E. (2000). Pharmacology of lemongrass (Cymbopogon Citratus). Assessment of eventual toxic, hypnotic and anxiolytic effects on human. Journal of Ethnopharmacology, 17, 75-83. https://doi.org/10.1016/0378-8741(86)90074-7

Lodhi, P., Tandan, N., Singh, N., \& Kumar, D. (2014) Green tea extract ameliorates ethanol induced liver injury in Albino rats. American Journal of Phytomedicine and Clinical Therapeutics, 2, 603-608.

Lonkar, P.B., Chavan, U.D., Pawar, V.D., Bansode, V.V., \& Amarowicz, R. (2013). Studies on preparation and preservation of lemongrass (Cymbopogon citratus) powder for tea. Emirates Journal of Food and Agriculture, 25, 585-592. https://doi.org/10.9755/ejfa.v25i8.15218

Martinazzo, P., Melo, E.C., Barbosa, L.C., De, A., Soares, N., De, F.F., Rocha, R.P., Randuz, L.L., \& Berbert, P.A. (2009). Quality parameters of Cymbopogon citratus leaves during ambient storage. Applied Engineering in Agriculture, 25, 543-547. https://doi.org/10.13031/2013.27457

Meilgaard, M., Civille, G.V., \&Carr, B.T. (1999). Sensory Evaluation Techniques. 3rd Edition CRC Press, Bocan Raton, Florida. pp. 387. https://doi.org/10.1201/9781439832271

Mirza, M., Askari, A., Yaqueen, Z., Ahmad, Z., \& Qadri, R.B. (2001). Diuretic studies on lemon grass tea from Cymbopogon citratus (DC) Stapf in rat. Pakistan Journal of Scientific and Industrial Research, 44, 96-100.

Nur Ain, A.H., Zaibunnisa, A.H., Halimahton, Z.M.S., \& Norashikin, S. (2013). An experimental design approach for the extraction of lemongrass (Cymbopogon citratus) oleoresin using pressurized liquid extraction (PLE). International Food Research Journal, 20, 451-455.

Nur Ain, A.H., Farah, D.M.H., \& Zaibunnisa, A.H. (2011). Encapsulation of lemongrass (Cymbopogon citratus) oleoresin with $\beta$-cyclo dextrin: Phase solubility study and its characterization. Internal Conference on Biotechnology and Food Science, 7, 44-48.

Ozkan, A.I., Akbudak, B., \& Akbudak, N. (2007). Microwave drying characteristics of spinach. Journal of Food Engineering, 78, 577-583. https://doi.org/10.1016/j.jfoodeng.2005.10.026

Rahimmalek, M., \& Goli, S.A.H. (2013). Evaluation of six drying treatments with respect to essential oil yield, composition and color characteristics of Thymys daenensis subsp. daenensis. celak leaves. Industrial Crops Production, 42, 613-619. https://doi.org/10.1016/j.indcrop.2012.06.012

Rahman, N.A., Tasirin, S.M., Razak, A.H.A., Mokhtar, M., \& Muslim, S. (2013). Comparison of drying parameter optimization of lemongrass. World Applied Science Journal, 24, 1234-1249.

Sanmeema, F., Abbasi, K., \&Bakhshi, K.G. (2012). Influence of drying and extraction methods on yield and chemical composition of the essential oil of Satureja hortensis. Food Chemistry, 99, 19-23.

Shaw, M., Meda, V., Tabil, L., \& Opoku, A. (2007). Drying and colour characteristics of coriander foliage using convective thin-layer and microwave drying. Journal of Microwave Power and Electron Energy, 41, 56-65. https://doi.org/10.1080/08327823.2006.11688559.

Somkiat, P., Paveena, P., \& Somchart, S. (2004). Effective diffusivity and kinetics of urease inactivation and colour change during processing of soybeans with superheated-steam fluidized bed. Drying Technology, 22, 2095-2118. https://doi.org/10.1081/DRT-200034265

Soysal, Y. (2004). Microwave drying characteristics of parsley. Biosystems Engineering, 89, 167-173. https://doi.org/10.1016/j.biosystemseng.2004.07.008

Tetteh, O.N.A. (2009). Effect of blanching and dehydration methods on the quality of moringa leaf powder used as herbal green tea. Kwane Nkrumah University of Science and Technology. pp. 58. 
Youssef, K.M., \& Mokhtar, S.M. (2014). Effect of drying methods on the antioxidant capacity, color and phytochemicals of Portulaca oleracea L. leaves. Journal of Nutrition and Food Science, 4, 322. https://doi.org/10.4172/2155-9600.1000322

Vargas, M., Chafer, M., Albors, A., Chiralt, A., \& Martinez, Gonzalez, C. (2008). Physicochemical and sensory characteristics of yoghurt produced from mixtures of cow's and goat's milk. International Dairy Journal, 18, 1146-1147. https://doi.org/10.1016/j.idairyj.2008.06.007

\section{Copyrights}

Copyright for this article is retained by the author(s), with first publication rights granted to the journal.

This is an open-access article distributed under the terms and conditions of the Creative Commons Attribution license (http://creativecommons.org/licenses/by/4.0/). 